\title{
ANALISIS STRATEGI PEMASARAN PARIWISATA DI DESA KETAPANG RAYA KECAMATAN KERUAK, LOMBOK TIMUR
}

\author{
Rusdiati Khairo*) \\ Lalu Adi Permadi**) \\ Dwi Putra Buana Sakti ${ }^{* * *}$
}

\begin{abstract}
The purpose of this study was to analyze tourism marketing strategies in Ketapang Raya Village, Keruak District, East Lombok. The type of research approach used by researchers in this study is the type of descriptive approach. While the type of research used is qualitative research. In determining the informants as sources of data in this study the authors used purposive sampling technique. The results showed that in the marketing strategy carried out by Ketapang Raya Village the marketing process was divided into several stages, starting with segmentation, targeting, positioning, marketing mix. The most effective marketing strategy is to use word of mouth promotion because visitors who have visited the tourist attraction in Ketapang Raya Village will influence their colleagues or family to visit the tourist attractions.
\end{abstract}

Keywords : Marketing Strategy, Tourism, SWOT Analysis, Marketing Mix

\section{Pendahuluan}

Indonesia merupakan negara kepulauan yang memiliki keindahan alam dan tempattempat wisata yang dapat mendukung perkembangan pariwisata. Kondisi geografis Indonesia yang memiliki banyak pesona keindahan dan sumber daya alam memberikan peluang bagi pemerintah untuk menjadikan sektor pariwisata sebagai sektor unggulan yang dapat berpengaruh dalam peningkatan pendapatan nasional. Keanekaragaman budaya juga menjadi salah satu daya tarik wisata kultural yang mampu mendorong keinginan wisatawan mancanegara untuk berwisata ke Indonesia.

Kabupaten Lombok Timur memiliki potensi pariwisata yang cukup banyak dan beragam seperti wisata alam, wisata sejarah dan wisata budaya yang dapat ditemukan di wilayah Kabuapten Lombok Timur ini. Menurut data dinas Kebudayaan dan Pariwisata Kabupaten Lombok Timur terdapat 106 objek wisata salah satunya yaitu berada di desa Ketapang Raya (Syukur et al., 2018). Salah satu desa yang memiliki potensi adalah Desa Ketapang Raya, Kecamatan Keruak, Kabupaten Lombok Timur (Lotim). Yang berada di wilayah pesisir pantai, dan berbatasan langsung dengan Kecamatan Jerowaru. Desa ini terbentuk, setelah pemekaran dari Desa Tanjung Luar.Kecamatan Keruak mempunyai Luas wilayah 1,2 km², dan Jumlah penduduknya 9.890 Jiwa dari 2.997 Kepala Keluarga dengan rincian laki-laki 4.296 Jiwa dan Perempuan.

Faktor keamanan dan kenyamanan merupakan faktor yang paling utama dalam dunia pariwisata, mengingat tujuan seorang wisatawan untuk melakukan perjalanan ke daerah wisata adalah untuk menenangkan diri. Apabila terjadi gangguan pada kondisi keamanan dan kenyamanan di daerah wisata maka otomatis minat dari para wisatawan untuk berkunjung ke daerah tersebut menjadi berkurang. Bencana gempa yang akhir-akhir ini menimpa Lombok tidak membuat para wisatawan takut untuk berkunjung ke objek wisata Desa Ketapang Raya. Meski melumpuhkan sector pariwisata khususnya Gunung

\footnotetext{
*) Fakultas Ekonomi dan Bisnis Unram, Email : rusdiaeyo@gmail.com

${ }^{* *}$ Fakultas Ekonomi dan Bisnis Unram, Email : adipermadi@unram.ac.id

${ }^{* * *}$ Fakultas Ekonomi dan Bisnis Unram, Email : buana@unram.ac.id
} 
Rinjani, namun beberapa daerah masih terpantau aman pasca gempa salah satunya yaitu Desa Ketapang Raya. Semua fasilitas yang ada di kawasan tersebut dalam kondisi baik dan tidak ada fasilitas yang mengalami kerusakan (Humaidi : 2015).

Strategi merupakan titik awal dalam pembuatan rencana yang dipilih oleh perusahaan untuk mencapai tujuan. Pengertian strategi secara umum adalah proses penentuan rencana para pemimpin puncak yang berfokus pada tujuan jangka panjang, disertai penyusunan suatu cara atau upaya bagaimana agar tujuan tersebut dapat dicapai. Strategi biasanya menjangkau masa depan, sehingga pada umumnya strategi disusun secara bertahap dengan memperhitungkan faktor-faktor yang mempengaruhinya. Untuk mencapai sebuah strategi yang telah ditetapkan dalam rangka mempunyai keunggulan kompetitif, maka para pimpinan haruslah bekerja dalam sebuah sistem yang ada pada proses perencanaan strategis atau strategic planning (Brown : 2005).

Suradnya dalam Suryadana dan Octavia (2015 : 97) mengatakan bahwa strategi pemasaran di tingkat destinasi seharusnya dimulai dengan penelitian untuk mengidentifikasi targettarget pasar destinasi pariwisata yang bersangkutan serta strategi pemasaran dan branding yang tepat bagi target-target pasar yang dituju. Pemasaran produk pariwisata membutuhkan strategi yang tepat agar potensi yang di miliki oleh Desa Ketapang Raya bisa dikembangkan secara optimal untuk meningkatkan jumlah kunjungan wisatawan. Pemasaran produk pariwisata beperan penting dalam mengembangkan potensi wisata dari ketatnya persaingan yang terjadi dalam merebut pangsa pasar pariwisata dan menjadi desinasi wisata yang terkenal. Dengan adanya strategi pemasaran maka akan membuat detail tujuan yang akan dicapai baik dalam jangka pendek maupun jangka panjang.

\section{Tinjauan Pustaka}

\subsection{Kajian Tentang Strategi Pemasaran}

Menurut David (2011 : 18-19) Strategi adalah sarana bersama dengan tujuan jangka panjang yang hendak dicapai. Strategi bisnis mencakup ekspansi georafis, diversifikasi, akusisi, pengembangan produk, penetrasi pasar, pengetatan, divestasi, likuidasi, dan usaha patungan atau joint venture. Strategi adalah aksi potensial yang membutuhkan keputusan manajemen puncak dan sumber daya perusahaan dalam jumlah besar. Jadi strategi adalah sebuah tindakan aksi atau kegiatan yang dilakukan oleh seseorang atau perusahaan untuk mencapai sasaran atau tujuan yang telah di tetapkan.

Menurut Tjiptono (2006 : 3) istilah strategi berasal dari bahasa Yunani yaitu strategi yang artinya seni atau ilmu untuk menjadi seorang jendral. Strategi juga bisa diartikan suatu rencana untuk pembagian dan penggunaan kekuatan militer pada daerah-daerah tertentu untuk mencapai tujuan tertentu. Sedangkan Menurut Pearce II dan Robinson (2008 : 2), strategi adalah rencana berskala besar, dengan orientasi masa depan, guna berinteraksi dengan kondisi persaingan untuk mencapai tujuan Perusahaan dari definisi tersebut, dapat di simpulkan bahwa pengertian dari Strategi adalah sebuah tindakan proses perencanaan untuk mencapai tujuan yang telah di tetapkan, dengan melalukan hal-hal yang besifat terus menerus sesuai keputusan bersama dan berdasarkan sudut pandang kebutuhan pelanggan.

\subsection{Analisis SWOT}

Menurut Duchan dalam Sondang (2000), menganalisa lingkungn internal dan eksternal merupakan hal penting dalam proses perencanaan strategi. Faktor-faktor lingkungan internal dalam peruahaan biasanya dapat digolongkan sebagai Strenghts $(S)$, Weaknesses $(W)$, Opportunitties $(O)$, atau threats $(T)$. Analisis lingkungan strategi ini disebut sebagai analisis SWOT. Sedangkan menurut Thompson dalam Sondang (2000), analisis SWOT adalah simpel tetapi merupakan alat bantu yang sangat kuat untuk memperbesar 
kapabilitas serta mengetahui ketidakefisienan sumber daya perusahaan, kesempatan dari pasar dan ancaman eksternal untuk masa depan agar lebih baik lagi.

Analisis SWOT (Strenghts, Weaknesses, Opportunitties, and threats) adalah analisis yang bertujuan untuk mengetahui perubahan lingkungan internal dan lingkungan eksternal. Dalam analisis lingkungan eksternal ditujukan terhadap berbagai perubahan, baik yang terjadi di lingkungn umum perusahaan maupun lingkungan industry atau lingkungan tugas. Tujuan yang ingin diperoleh melalui pelaksanaan kegiatan analisis lingkungan eksternal adalah mengidentifikasi adanya berbagai peluang dan ancaman. Peluang dan ancaman merupakan bagian dari analisis SWOT (Solihin ; 2002).

\subsection{Kajian tentang Pariwisata}

Pariwisata merupakan bagian yang tidak terpisahkan dari kehidupan manusia terutama menyangkut kegiatan sosial ekonomi. Diawali dari kegiatan yang semula hanya dinikmati oleh segelintir orang yang relatif kaya pada awal abad ke-20, dan kini telah menjadi bagian dari hak asasi manusia. Hal ini tidak hanya terjadi di negara maju tetapi mulai dirasakan pula di negara berkembang. Menurut Soekadijo (2000 : 453) menjelaskan pariwisata secara singkat dapat dirumuskan sebagai kegiatan dalam masyarakat yang berhubungan dengan wisatawan. Pariwisata merupakan bagian yang tidak terpisahkan dari kehidupan manusia terutama menyangkut kegiatan sosial dan ekonomi.

Menurut Undang-Undang Nomor 10 tahun 2009 tentang kepariwisataan menyebutkan bahwa pariwisata adalah berbagai macam kegiatan wisata dan di dukung berbagai fasilitas serta layanan yang disediakan oleh masyarakat, pengusaha, pemerintah, dan pemerintah daerah. Sedangkan Menurut Yuliani (2013 : 453) menjelaskan bahwa pariwisata merupakan istilah yang diberikan apabila seseorang Wisatawan melakukan perjalanan itu sendiri, atau dengan kata lain aktivitas dan kejadian yang terjadi ketika seseorang pengunjung melakukan perjalanan .

Berdasarkan definisi-definisi pariwisata diatas, maka dapat disimpulkan bahwa kegiatan pariwisata adalah seseorang yang melakukan kunjungan atau perjalanan seseorang dalam waktu sementara dengan motif yang bermacam - macam baik itu untuk besenang - senang, perjalananan bisnis dan lain sebagainya dengan fasilitas yang telah di sediakan.

\subsection{Kajian Tentang Wisatawan}

Jika ditinjau dari arti kata "wisatawan" yang berasal dari kata "wisata" maka sebenarnya tidaklah tepat sebagai pengganti kata "tourist" dalam bahasa Inggris. Kata itu berasal dari bahasa Sansekerta "wisata" yang berarti "perjalanan" yang sama atau dapat disamakan dengan kata "travel" dalam bahasa Inggris. Jadi orang melakukan perjalanan dalam pengertian ini, maka wisatawan sama artinya dengan kata "traveler" karena dalam bahasa Indonesia sudah merupakan kelaziman memakai akhiran "wan" untuk menyatakan orang dengan profesinya, keahliannya, keadaannya jabatannya dan kedudukan seseorang (Irawan, $2010: 12$ ).

Travel and Tourism di Roma 1963 (dalam Irawan, 2010 : 12), menggunakan istilah pengunjung (visitor) untuk setiap orang yang datang ke suatu negara yang bukan tempat tinggalnya yang biasa untuk keperluan apa saja, selain melakukan perjalanan yang digaji. Pengunjung yang dimaksudkan meliputi 2 kategori yaitu wisatawan adalah pengunjung yang datang ke suatu negara yang dikunjunginya tinggal selama 24 jam dan dengan tujuan untuk bersenang-senang, berlibur, kesehatan, belajar, keperluan agama dan olahraga, bisnis, keluarga, utusan dan pertemuan dan excurtionist yaitu : pengunjung yang hanya tinggal sehari di negara yang dikunjunginya tanpa bermalam. 


\section{Desain Penelitian \\ 3.1. Pendekatan Penelitian}

Tipe pendekatan penelitian yang digunakan oleh peneliti dalam penelitian ini yaitu tipe pendekatan deskriptif. Sedangkan jenis penelitian yang dipakai adalah penelitian kualitatif.

\subsection{Setting Lokasi}

Penelitian ini berlokasi di Desa Ketapang Raya, Kecamatan Keruak, Kabupaten Lombok Timur (Lotim), berada di wilayah pesisir pantai, dan berbatasan langsung dengan Kecamatan Jerowaru.

\subsection{Prosedur Pengumpulan data}

Prosedur pengumpulan daya yang digunakan yaitu wawancara. Wawancaradilakukan dengan cara mendalam guna mendapatkan informasi terkait strategi pemasaran pariwisata di Desa Ketapang Raya. Selain melakukan wawancara secara tidak langsung kepada informan, untuk memperoleh data tambahan serta mencocokkan data yang ada, maka peneliti melakukan observasi. Metode pengumpulan data pada penelitian ini adalah dengan obsrvasi secara langsung, wawancara dengan masyarakat sekitar dan stake holder serta. Penggunaan metode dokumentasi ditujukan untuk melengkapi dan memperkuat data dari hasil wawancara, sehingga diharapkan dapat diperoleh data yang lengkap, menyeluruh dan memuaskan

\section{Hasil Dan Pembahasan}

\subsection{Analisis SWOT}

Pada tahapan ini peneliti menggunakan analisa SWOT guna mendapatkan strategi baru untuk pemasaran Desa Ketapang Raya, dimana metode ini menunjukan kinerja dari Desa Ketapang Raya dengan cara menentukan perpaduan faktor internal dan eksternal. Analisis SWOT membandingkan antara kedua faktor tersebut, dimana yang masuk ke dalam faktor internal yaitu kekuatan (strength) dan Kelemahan (weakness) serta faktor eksternal yaitu peluang (opportunity), dan ancaman (threats). Pada Dasarnya semua permasalahan dalam persaingan dan pemasaran Desa Ketapang Raya dikelompokan menjadi kekuatan, kelemahan, peluang, dan ancaman.

\subsection{Identifikasi Lingkungan Internal Dan Eksternal}

Dalam penentuan perumusan strategi, maka sebelumnya dilakukan identifikasi terhadap faktor-faktor penting untuk penentuan strategi. Analisis situasi dilakukan pada faktor lingkungan internal dan faktor lingkungan eksternal yang secara langsung dapat mempengaruhi pencapaian tingkat kinerja dalam pengembangan potensi pariwisata di Desa Ketapang Raya maka dalam menentukan peluang dan konsep pemasaran wisata di Desa Ketapang Raya, ada 2 (dua) aspek yang sangat berpengaruh untuk ditinjau, yaitu dengan tinjauan terhadap aspek lingkungan eksternal, dan aspek lingkungan internal. Dari kedua aspek tersebut dapat dilihat peluang pengembangan dengan menggunakan sistem analisis SWOT. 


\subsubsection{Model Matrik Analisis SWOT}

Tabel 4.2.1. Model Matrik Analis SWOT

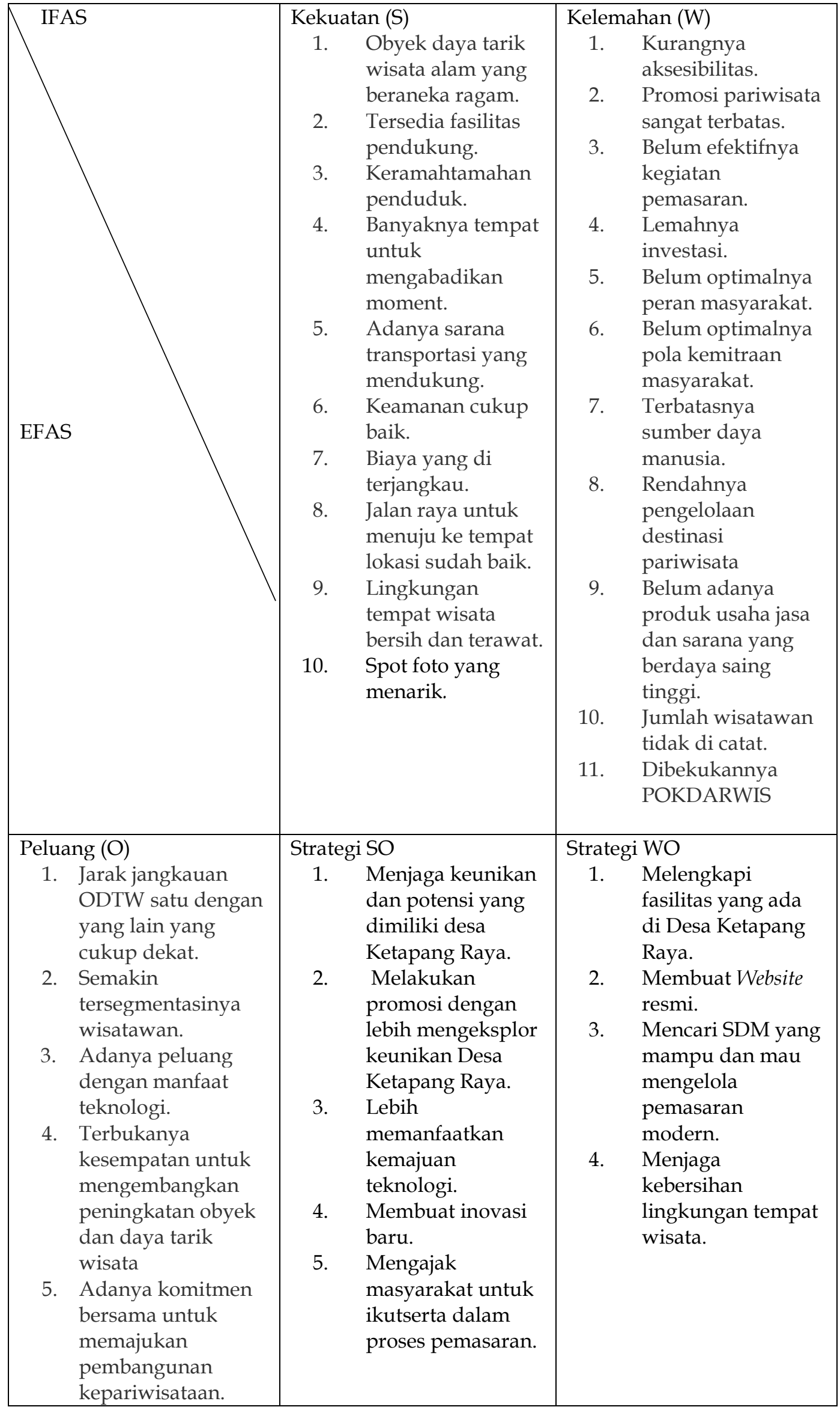




\begin{tabular}{|c|c|c|c|}
\hline $\begin{array}{l}\text { 6. } \\
\text { pebijakan } \\
\text { pemerintah daerah } \\
\text { untuk } \\
\text { mengembangkan } \\
\text { pariwisata berbasis } \\
\text { ekowisata. } \\
\end{array}$ & & & \\
\hline $\begin{array}{l}\text { Ancaman (T) } \\
\text { 1. } \text { Kelestarian } \\
\text { lingkungan akan } \\
\text { terancam oleh } \\
\text { kepentingan lain } \\
\text { yang menghasilkan } \\
\text { pendapatan lebih } \\
\text { besar. } \\
\text { 2. } \text { Promosi yang } \\
\text { kurang gencar } \\
\text { berakibat kepada } \\
\text { kelesuan bisnis } \\
\text { usaha pariwisata. } \\
\text { 3. Apresiasi dan } \\
\text { kecintaan } \\
\text { masyarakat } \\
\text { terhadap produk } \\
\text { lokal masih rendah } \\
\text { karena keterbatasan } \\
\text { informasi. } \\
\text { 4. Adanya kesamaan } \\
\text { potensi } \\
\text { kepariwisataan } \\
\text { dengan daerah lain. } \\
\text { 5. Masuknya } \\
\text { pengaruh budaya } \\
\text { asing yang } \\
\text { berkembang di } \\
\text { masyarakat. } \\
\text { Meningkatnya } \\
\text { minat masyarakat } \\
\text { sendiri untuk } \\
\text { melakukan } \\
\text { perjalanan wisata } \\
\text { ke daerah lain. }\end{array}$ & $\begin{array}{r}\text { Strat } \\
1 . \\
\\
\\
2 .\end{array}$ & $\begin{array}{l}\text { i ST } \\
\text { Lebih menonjolkan } \\
\text { ciri khas dan } \\
\text { keunikan Desa } \\
\text { Ketapang Raya . } \\
\text { Membuat strategi } \\
\text { alternatif untuk } \\
\text { mengatasi saat } \\
\text { terjadinya bencana } \\
\text { alam. } \\
\text { Mengontrol } \\
\text { aktifitas } \\
\text { masyarakat dan } \\
\text { wisatawan agar } \\
\text { tidak merusak } \\
\text { lingkungan. } \\
\text { Membuat inovasi } \\
\text { baru atraksi wisata } \\
\text { Desa Ketapang } \\
\text { Raya. } \\
\text { Meninggalkan } \\
\text { kesan yang baik } \\
\text { bagi pengunjung } \\
\text { karena setiap } \\
\text { orang yang } \\
\text { berkunjung akan } \\
\text { meceritakan kesan } \\
\text { baik atau buruk } \\
\text { yang dialaminya } \\
\text { kepada orang lain. }\end{array}$ & $\begin{aligned} & \text { Strategi WT } \\
& \text { 1. } \text { Membuat Website } \\
& \text { resmi . } \\
& \text { 2. } \text { POKDARWIS } \\
& \text { harus dibentuk } \\
& \text { ulang. } \\
& \text { 3. } \text { Memperbanyak } \\
& \text { pelatihan untuk } \\
& \text { masyarakat. } \\
& \text { 4. } \text { Meningkatkan } \\
& \text { sarana promosi. } \\
& \text { 5. } \text { Tetap mengadakan } \\
& \text { Event yang } \\
& \text { masyarakat Desa } \\
& \text { Ketapang Raya } \\
& \text { seperti dayung } \\
& \text { sampan atau kano } \\
& \text { setiap tahun baru. }\end{aligned}$ \\
\hline
\end{tabular}

\subsubsection{Hasil Perhitungan IFAS}

4.2.2. Tabel Hasil Perhitungan IFAS

\begin{tabular}{|l|l|c|c|c|c|}
\hline No & \multicolumn{1}{|l|}{ Faktor Strategi Internal } & Jumlah & $\begin{array}{c}\text { Bobot } \\
\%\end{array}$ & rating & skor \\
\hline & Kekuatan & & \\
\hline 1 & $\begin{array}{l}\text { Obyek daya tarik wisata } \\
\text { alam yang beraneka ragam. }\end{array}$ & 16 & 0,07 & 4 & 0,28 \\
\hline 2 & Keamanan cukup baik & 16 & 0,07 & 4 & 0,28 \\
\hline
\end{tabular}




\begin{tabular}{|c|c|c|c|c|c|}
\hline 3 & $\begin{array}{l}\text { Tersedia fasilitas } \\
\text { pendukung }\end{array}$ & 16 & 0,07 & 4 & 0,28 \\
\hline 4 & $\begin{array}{l}\text { Banyaknya tempat untuk } \\
\text { mengabadikan moment }\end{array}$ & 16 & 0,07 & 4 & 0,28 \\
\hline 5 & Biaya yang di terjangkau. & 16 & 0,07 & 4 & 0,28 \\
\hline 6 & $\begin{array}{l}\text { Jalan raya untuk menuju ke } \\
\text { tempat lokasi sudah baik }\end{array}$ & 12 & 0,05 & 3 & 0,15 \\
\hline 7 & $\begin{array}{l}\text { Memiliki pemandangan } \\
\text { yang indah }\end{array}$ & 16 & 0,07 & 4 & 0,28 \\
\hline 8 & $\begin{array}{l}\text { Lingkungan tempat wisata } \\
\text { bersih dan terawat. }\end{array}$ & 12 & 0,05 & 3 & 0,15 \\
\hline 9 & Adanya sarara transportasi & 12 & 0,05 & 3 & 0,15 \\
\hline \multirow[t]{2}{*}{10} & Penduduk ramah & 16 & 0,07 & 4 & 0,28 \\
\hline & \multicolumn{5}{|l|}{ Kelemahan } \\
\hline 1 & $\begin{array}{l}\text { Obyek dan daya tarik } \\
\text { wisata kurang memiliki } \\
\text { daya saing. }\end{array}$ & 4 & 0,01 & 1 & 0,01 \\
\hline 2 & $\begin{array}{l}\text { Promosi pariwisata sangat } \\
\text { terbatas. }\end{array}$ & 8 & 0,03 & 2 & 0,06 \\
\hline 3 & $\begin{array}{l}\text { Belum efektifnya kegiatan } \\
\text { pemasaran }\end{array}$ & 8 & 0,03 & 2 & 0,06 \\
\hline 4 & Lemahnya investasi. & 8 & 0,03 & 2 & 0,06 \\
\hline 5 & $\begin{array}{l}\text { Belum optimalnya peran } \\
\text { masyarakat }\end{array}$ & 12 & 0,05 & 3 & 0,15 \\
\hline 6 & $\begin{array}{l}\text { Terbatasnya sumber daya } \\
\text { manusia. }\end{array}$ & 12 & 0,05 & 3 & 0,15 \\
\hline 7 & $\begin{array}{l}\text { Rendahnya pengelolaan } \\
\text { destinasi pariwisata }\end{array}$ & 8 & 0,03 & 2 & 0,06 \\
\hline 8 & $\begin{array}{l}\text { Belum adanya produk } \\
\text { usaha jasa dan sarana yang } \\
\text { berdaya saing tinggi }\end{array}$ & 8 & 0,03 & 2 & 0,06 \\
\hline 9 & $\begin{array}{l}\text { Biro perjalanan masih } \\
\text { sangat terbatas. }\end{array}$ & 12 & 0,05 & 3 & 0,15 \\
\hline 10 & $\begin{array}{l}\text { Kurangnya pemahaman } \\
\text { masyarakat terhadap } \\
\text { pelestarian objek wisata. }\end{array}$ & 8 & 0,03 & 2 & 0,06 \\
\hline & Jumlah & 224 & 0,98 & & 4,1 \\
\hline
\end{tabular}

\subsubsection{Hasil Perhitungan EFAS}

4.2.4. Tabel Hasil Perhitungan EFAS

\begin{tabular}{|l|l|c|c|c|c|}
\hline No & Faktor Strategi Eksternal & Jumlah & $\begin{array}{c}\text { Bobot } \\
\%\end{array}$ & Rating & Skor \\
\hline \multicolumn{5}{|l|}{ Peluang } \\
\hline 1 & $\begin{array}{l}\text { Jarak jangkauan ODTW } \\
\text { satu dengan yang lain } \\
\text { yang cukup dekat. }\end{array}$ & 16 & 0,11 & 3,5 & 0,3 \\
\hline
\end{tabular}




\begin{tabular}{|c|c|c|c|c|c|}
\hline 2 & $\begin{array}{l}\text { Semakin } \\
\text { tersegmentasinya } \\
\text { wisatawan }\end{array}$ & 12 & 0,07 & 3 & 0,21 \\
\hline 3 & $\begin{array}{l}\text { Adanya peluang dengan } \\
\text { manfaat teknologi. }\end{array}$ & 16 & 0,11 & 3,5 & 0,3 \\
\hline 4 & $\begin{array}{l}\text { Terbukanya kesempatan } \\
\text { untuk mengembangkan } \\
\text { peningkatan obyek dan } \\
\text { daya tarik wisata }\end{array}$ & 16 & 0,11 & 3,5 & 0,3 \\
\hline 5 & $\begin{array}{l}\text { Adanya komitmen } \\
\text { bersama untuk } \\
\text { memajukan } \\
\text { pembangunan } \\
\text { kepariwisataan. }\end{array}$ & 12 & 0,07 & 3 & 0,21 \\
\hline 6 & $\begin{array}{l}\text { Kebijakan pemerintah } \\
\text { daerah untuk } \\
\text { mengembangkan } \\
\text { pariwisata berbasis } \\
\text { ekowisata. }\end{array}$ & 16 & 0,11 & 3,5 & 0,3 \\
\hline \multicolumn{6}{|c|}{ Ancaman } \\
\hline 1 & $\begin{array}{l}\text { Kelestarian lingkungan } \\
\text { akan terancam oleh } \\
\text { kepentingan lain yang } \\
\text { menghasilkan } \\
\text { pendapatan lebih besar. }\end{array}$ & 12 & 0,07 & 3 & 0,21 \\
\hline 2 & $\begin{array}{l}\text { Promosi yang kurang } \\
\text { gencar berakibat kepada } \\
\text { kelesuan bisnis usaha } \\
\text { pariwisata. }\end{array}$ & 8 & 0,05 & 3 & 0,21 \\
\hline 3 & $\begin{array}{l}\text { Apresiasi dan kecintaan } \\
\text { masyarakat terhadap } \\
\text { produk lokal masih } \\
\text { rendah karena } \\
\text { keterbatasan informasi. }\end{array}$ & 12 & 0,07 & 3 & 0,21 \\
\hline 4 & $\begin{array}{l}\text { Adanya kesamaan } \\
\text { potensi kepariwisataan } \\
\text { dengan daerah lain }\end{array}$ & 12 & 0,07 & 3 & 0,21 \\
\hline 5 & $\begin{array}{l}\text { Masuknya pengaruh } \\
\text { budaya asing yang } \\
\text { berkembang di } \\
\text { masyarakat. }\end{array}$ & 12 & 0,07 & 3 & 0,3 \\
\hline 6 & $\begin{array}{l}\text { Meningkatnya minat } \\
\text { masyarakat sendiri untuk } \\
\text { melakukan perjalanan } \\
\text { wisata ke daerah lain. }\end{array}$ & 8 & 0,05 & 2 & 0,1 \\
\hline & Jumlah & 156 & 0,98 & & 2,86 \\
\hline
\end{tabular}

\section{Keterangan :}

$1=$ Tidak Setuju

$2=$ Kurang Setuju

$3=$ Netral

$4=$ Setuju

$5=$ Sangat Setuju 


\section{a) Produk}

4.3. Strategi Pemasaran di Desa Ketapang Raya Berdasarkan Analisis SWOT

Produk yang ditawarkan Desa Ketapang Rayakepada wisatawan dari dulu sampai saat ini tidak terlalu banyak mengalami perubahan akan tetapi hanya lebih dikemas dengan baik agar wisatawan lebih tertarik untuk mengunjungi DesaKetapang Raya. Berikut adalah produk dan atraksi yaitu:

1. Karaoke gratis di pantai Lungkak,

2. Obyek daya daya tarik wisata alam beragam, seperti Gili Bembeq, Pulau Pasir dan melihat budidaya lobster di keramba jaring apung,

3. Pemandangan alam yang indah seperti sunset di pantai Lungkak, sunrise di pantai Lungkak,

4. Lingkungan yang bersih,

5. Penduduk ramah,

6. Spot foto yang menarik seperti ayunan bambu couple, air mancur, taman, spot foto berbentuk love, ayunan sunrise couple.

\section{b) Promosi}

1. Promosi merupakan salah satu cara efektif yang diambil olehDesa Ketapang Rayauntuk menawarkan dan memperkenalkan produk desake wisatawan. Desa Ketapang Raya sudah menggunakan beberapa jenis promosike berbagai media. Adapun jenis promosi yang digunakan sebagai berikut: Media sosial instagram yang bisa diakses melalui https://www.instagram.com/explore.ketapangraya/

2. Facebook bang diakses melalui https://www.facebook.com/wisatalungkak/?ref=br_rs

3. Youtube yang bisa diakses melalui https://www.youtube.com/channel/UCR9VLjCRNM3zx3-dqzxkJMQ

4. Event tahunan yang diadakan pengurus Desa Ketapang Raya seperti dayung sampan atau kano.

5. Melalui mulut ke mulut.

\section{c) Personalia}

Dalam proses pemasaran khususnya proses penawaran produk, orang yang menawarkan produk yaitu pengurus dibantu dengan karang taruna dan masyarakat Desa Ketapang Raya. Sumber Daya Manusia Desa Ketapang Raya dalam pemasaran dan pelayanan kepada wisatawan cukup merata dan baik. Meskipun dari anggota dan pengurus sebagian besar tidak memiliki latar belakang pariwisata melainkan dari latar belakang pedagang dan nelayan. Untuk latar belakang pendidikan masyarakat di Desa Ketapang Raya sendiri rata-rata yaitu lulusan SMP dan SMA. POKDARWIS yang dibekukan akan dibentuk ulang sebagai pengurus pariwiwisata, mencari SDM yang mampu dan mau mengelola pemasaran modern dan melakukan pelatihan-pelatihan kepada masyarakat setempat.

\section{d) Bukti Fisik}

Bukti fisik atau physical evidence merupakan suatu komponen pemasaran yang sangat penting dan berpengaruh dalam pemasaran Desa Ketapang Raya, karena bukti fisik merupakan hal yang langsung dapat dilihat oleh wisatawan sehingga tidak dapat dihindari dan disembunyikan. Untuk bukti fisik yang ada di Desa Ketapang Raya dimulai dari produk, fasilitas, sarana dan prasarana aksesibilitas dan lain sebagiannya, dapat dikatakan sangat baik dan lengkap. Hal tersebut dapat dibuktikan dengan ketersediaan produk, fasilitas pendukung, sarana dan prasarana. Adapun fasilitas yang sediakan yaitu:

1. Berugak,

2. Warung atau cafe,

3. Tempat parkir, 
4. Penunjuk arah,

5. Toilet,

6. Spot selfie yang menarik,

7. Banyaknya tempat sampah,

8. Adanya kesediaan transportasi menuju tempat wisata.

\section{Penutup}

5.1. Simpulan

Hasil penelitian yang dilakukan terhadap strategi pemasaran pariwisata di Desa Ketapang Raya Kecamatan Keruak, Lombok Timur dapat disimpulkan sebagai berikut :

1. Produk

Dalam strategi pemasaran produk, pariwisata di Desa Ketapang Raya tidak hanya menawarkan potensi alam untuk menarik pengunjung, akan tetapi pariwisata di Desa Ketapang Raya dikemas lebih menarik seperti banyaknya spot foto yang telah disedikan, melihat langsung budidaya lobster dan karaoke gratis.

2. Promosi Promosi yang digunakan ketapang Raya yaitu :
a. Media sosial instagram yang bisa diakses melalui https://www.instagram.com/explore.ketapangraya/
b. Facebook bisa diakses melalui https://www.facebook.com/wisatalungkak/?ref=br_rs
c. Youtube yang bisa diakses melaui https://www.youtube.com/channel/UCR9VLjCRNM3zx3-dqzxkJMQ
d. Event tahunan yang diadakan pengurus Desa Ketapang Raya seperti dayung sampan atau kano.
e. Melalui mulut ke mulut.

3. Personalia

Strategi pemasaran yang akan dilakukan Desa Ketapang Raya dalam mengurus pariwisata yaitu:

a. POKDARWIS yang dibekukan akan dibentuk ulang sebagai pengurus pariwiwisata.

b. Mencari SDM yang mampu dan mau mengelola pemasaran modern.

c. Melakukan pelatihan-pelatihan kepada masyarakat setempat.

\section{Bukti Fisik}

Untuk bukti fisik yang ada di Desa Ketapang Raya dimulai dari produk, fasilitas, sarana dan prasarana aksesibilitas dan lain sebagiannya, dapat dikatakan sangat baik, akan tetapi pengurus Desa Ketapang Raya akan terus melengkapi fasilitas yang ada seperti membuat inovasi baru atraksi wisata Desa Ketapang Raya.

\section{Saran}

1. Masyarakatlkut berpartisipasi aktif dengan pihak pengelola destinasi terkait dengan segala kebijakan yang dibuat oleh pengelola destinasi. Hal terbut dilakukan karena setiap kebijakan yang dibuat oleh pihak pengurus pasti.

2. Pengurus perlu berkoordinasi kepada masyarakat untuk mengatasi permasalahan saat berkurangnya jumlah wisatawan.

\section{Keterbatasan penelitian}

1. Hasil dari temuan dari penelitian ini terbatas pada konteks penelitian ini sajaartinya belum tentu hasilnya sama untuk konteks penelitian yang berbeda.

2. Kesulitan Peneliti untuk membuat janji dengan pihak pengurus sehingga peneliti harus datang lebih inten untuk menemui informan dan mencari waktu luangnya. 


\section{DAFTAR PUSTAKA}

Astutik, Y. 2016. Analisis Strategi Pemasaran Ekowisata Green Hill Park Taman Wisata Alam Cimanggu Kabupaten Bandung- Jawa Barat. (Skripsi Sarjana, Institute Pertanian Bogor).

Brown, R.G, Burns T. 2005. Lecture Notes Dermatologi. Jakarta: Erlangga

Buchari, Alma. 2007. Manajemen Pemasaran Dan Pemasaran Jasa. Edisi Revis. Bandung : CV. Alfabeta.

Darmawan, Yudha.2016. Strategi Pemasaran Pariwisata dalam Upaya Menjaga Keunikan Desa Wisata (Studi Kasus di Desa Wisata Samiran, Kecamatan Selo Kabupaten Boyolali).(Artikel Ilmiah, Universitas Kristen Satya Wacana Salatiga).

David, Fred R. 2011. Strategic Management, Buku 1. Edisi 12 Jakarta.

Emzir. 2011. Metodologi Penelitian Kualitatif Analisis Data. Jakarta : Rajawali

Faisal, Sanapiah. 1990. Penelitian Kualitatif: Dasar-dasar Aplikas. Bandung: Yayasan Asih Asah Asuh.

Humaidi, Luthfi. 2015. Strategi Pemasaran Wisata Pasir Putih Dagelan, Kabupaten Gresik. (Skripsi Sarjana, UIN. Sunan Ampel Surabaya).

Irawan, Koko. 2010. Potensi Obyek Wisata Sebagai Daya Tarik Wisata. Yogyakarta : Kertas Karya

Komariah, Aan, Djam'an Satori. 2011. Metode penelitian kualitatif. Bandung : Alfabeta.

Kotler, Philip.1997. Manajemen Pemasaran. Jakarta : Prentice Hall

Kotler, Philip. 2000. Manajemen Pemasaran. Jakarta : PT.Prenhallindo.

Kotler dan Amstrong. 2001. Prinsip-Prinsip Pemasaran, Edisi Keduabelas, Jilid 1. Jakarta : Erlangga.

Kotler dan Amstrong. 2004. Prinsip-prinsip Marketing, Edisi Ketujuh. Jakarta : Salemba Empat.

Kotler dan Amstrong. 2012. Prinsip-prinsip pemasaran. Edisi 13. Jakarta : Erlangga

Kotler dan Keller. 2009. Manajemen Pemasaran, Jilid 1, Edisi ke 13. Jakarta : Erlangga.

Kusumaningrum, Dian. 2009. Persepsi Wisatawan Nusantara Terhadap DayaTarik Wisata. Yogyakarta : Kajian.

Moleong,J. 2007. Metode Penelitian Kualitatif, Bandung : PT Rosdakarya.

Napitupulu, N.U. 2015. Strategi Pemasaran Pariwisata Budaya Mentawai Melalui Produk Kesenian Muturuk. (Skripsi Sarjana, Universitas Mercu Buana Jakarta). 
Pendit, Nyoman S. 2006. Ilmu pariwisata (sebuah pengantar perdana). Jakarta : PT Pradya Paramita.

Pearche II, John A. dan Robinson Richard B.Jr. 2008. Manajemen Strategis 10. Jakarta : Salemba Empat.

Pitana, I Gede dan Gayatri, Putu G. 2005. Sosiologi Pariwisata. Yogyakarta : Andi.

Rangkuti, Freddy. 2013. Teknik Membelah Kasus Bisnis Analisis SWOT Cara Perhitungan Bobot, Rating, dan OCAI. Jakarta: PT. Gramedia Pustaka Utama.

Soekadijo, R. G. 2000. Anatomi Pariwisata. Jakarta : PT. Gramedi Pustaka Utama.

Solihin, Ismail. 2002. Pengantar Manajemen. Jakarta : Erlangga.

Sondang P. Siagian. 2000. Manajemen Strategik. Jakarta : Bumi Aksara.

Stanton, William J. 2001. Prinsip-prinsip pemasaran. jilid ketujuh. Jakarta : Erlangga.

Sugiyono. 2011. Metode Penelitian Kuantitatif Kualitatif Dan R \& B. Bandung : Alfhabeta

Suryadana, M. Liga \& Octavia, Vanny. 2015. Pengantar pemasaran pariwisata. Bandung : Alfabeta.

Syukur A, Agil Al Idrus, Lalu Zulkifli. 2018. Pemberdayaan Kelompok Nelayan Pembudidaya Ramah Lingkungan Berbasis Ekowisata Di Desa Ketapang Raya Lombok Timur. Usul Program Pengabdian Masyarakat. Universitas Mataram.

Tjiptono, Fandy. 2000. Manajemen Jasa, Edisi Kedua. Yogyakarta : Andi Offset.

Tjiptono, Fandy. 2006. Manajemen Jasa. Edisi Pertama. Yogyakarta : Andi.

Undang-Undang Republik Indonesia Nomor 10 Tahun 2009 Tentang Kepariwisataan.

Widiastini, N.M. 2012. Strategi Pemasaran Pariwisata Di Kabupaten Buleleng, Bali. Jurnal Ilmu Sosial Dan Humaniora.

Yoeti, Oka A. 1991. Pengantar Ilmu Pariwisata. Bandung : Angkasa.

Yoeti, Oka A. 2006. Perencanaan dan pengembangan pariwisata. Jakarta : Pradnya Paramita.

Yoeti, Oka A. 2008. Pemasaran Pariwisata. Jakarta : Pradnya Paramita.

Yuliani. 2013. Strategi Komunikasi Dinas Kebudayaan Pariwisata dan Kominfo (Disbupdar) Dalam Meningkatkan Kunjungan Wisatawan di Desa Pampang Kota Samarinda. 